\title{
PENGARUH COVID-19 TERHADAP PEKERJA, BURUH, DAN USAHA MIKRO DI KABUPATENTANGERANG
}

\author{
Desy Apriani ${ }^{1}$, Wahyu Rama Ade Martha ${ }^{2}$, Yayat Supriatna ${ }^{3}$ \\ Program program Studi Sistem Informasi ${ }^{1,2}$, Program Studi Teknik Informatika ${ }^{3}$ \\ Email : desy@raharja.info, wahyu.rama@raharja.info, yayat.supriatna@raharja.info
}

\begin{abstract}
Termination of employment, the impact on unemployment, difficulty finding work, the poor increase. Prediction of an increase in the number of poverty in Indonesia. The Corona Virus then appeared and gave so much influence in various sectors. One of the sectors that was affected and felt so much was the economic sector. This study aims to determine the effect of Covid-19 on Workers, Labor, and Micro Enterprises in Kab. Tangerang. This research uses descriptive qualitative method. In collecting data using primary data, namely by using data collection techniques in-depth interviews, observation, and documentation. The Covid-19 pandemic not only has an impact on health, but also has an impact on the community's economy, especially informal workers who rely heavily on daily income. Based on the results of the study, it can be concluded that the Pandemic can also have a disproportionate economic impact on certain segments of the population, which can exacerbate inequality that affects most groups of workers, such as: Workers who already have problems with health conditions, Youth who are already facing unemployment and underemployment rates. higher unemployment, Older workers who may be at higher risk of serious health problems and likely to suffer from economic vulnerability, Women who are overrepresented in work who are on the front lines of dealing with the pandemic and who will bear a disproportionate burden of care responsibilities related to school closures or care systems Unprotected workers, including self-employed, casual and performance workers who do not have access to paid or sick leave mechanisms and migrant workers who may not be able to access the workplace $m$ them in the destination country or return to their families. Uncertainty and difficulties in life make this vulnerable group need social safety nets, such as health insurance and social security. Through the provision of health insurance and social security, the lives of the most vulnerable people are protected, both in times of crisis and in times of crisis. With this social protection, vulnerable workers can live in healthy conditions and can still work to support themselves and their families in the future. Without health insurance and social security, the crisis due to the Covid-19 pandemic will take away the hopes and lives of vulnerable groups
\end{abstract}

Keywords: Covid-19, economic impact, community economy 


\begin{abstract}
Abstrak
Pemutusan hubungan kerja, berdampak kepada pengangguran, kesulitan mencari pekerjaan, masyarakat miskin meningkat. Prediksi peningkatan jumlah kemiskinan di Indonesia. Virus Corona kemudian muncul dan memberikan begitu banyak pengaruh dalam berbagai sektor. Salah satu sektor yang terdampak dan begitu terasa adalah sektor ekonomi. Penelitian ini bertujuan untuk mengetahui pengaruh Covid-19 terhadap Pekerja, Buruh, dan Usaha Mikro di Kab. Tangerang. Penelitian ini menggunakan metode kualitatif deskriptif. Dalam pengumpulan datanya menggunakan data primer, yaitu dengan menggunakan teknik pengumpulan data wawancara mendalam, observasi, dan dokumentasi. Pandemi Covid-19 tidak hanya berdampak pada hal kesehatan, namun juga berdampak pada perekonomian masyarakat, khususnya para pekerja informal yang sangat bergantung pada penghasilan harian. Berdasarkan hasil penelitian dapat disimpulkan, Pandemi juga dapat memberikan dampak ekonomi yang tidak proporsional pada segmen populasi tertentu, yang dapat memperburuk ketimpangan yang mempengaruhi sebagian besar kelompok pekerja, seperti: Pekerja yang sudah memiliki masalah dengan kondisi kesehatan, Pemuda yang sudah menghadapi tingkat pengangguran dan setengah pengangguran yang lebih tinggi, Pekerja yang lebih tua yang mungkin berisiko lebih tinggi mengalami masalah kesehatan yang serius dan kemungkinan menderita kerentanan ekonomi, Wanita yang terlalu terwakili dalam pekerjaan yang berada di garis depan dalam menghadapi pandemi dan yang akan menanggung beban tanggung jawab perawatan yang tidak proporsional terkait dengan penutupan sekolah atau sistem perawatan Pekerja yang tidak terlindungi, termasuk wiraswasta, pekerja lepas dan pekerja pertunjukan yang tidak memiliki akses ke mekanisme cuti berbayar atau sakit dan pekerja migran yang mungkin tidak dapat mengakses tempat kerja mereka di negara tujuan atau pulang ke keluarganya. Ketidakpastian dan kesulitan hidup membuat kelompok rentan ini membutuhkan jaring pengaman sosial, seperti jaminan kesehatan dan jaminan sosial. Melalui penyediaan asuransi kesehatan dan jaminan sosial, kehidupan masyarakat yang paling rentan terlindungi, baik pada saat krisis maupun pada saat krisis. Dengan perlindungan sosial ini, pekerja rentan dapat hidup dalam kondisi sehat dan tetap dapat bekerja untuk menghidupi diri dan keluarganya di masa depan. Tanpa jaminan kesehatan dan jaminan sosial, krisis akibat pandemi Covid-19 akan merenggut harapan dan kehidupan kelompok rentan.
\end{abstract}

Kata Kunci : Covid-19, dampak ekonomi, perekonomian masyarakat

\title{
1. PENDAHULUAN
}

Virus corona saat ini telah memicu krisis kesehatan dunia, termasuk di Indonesia. Corona virus (COVID-19) adalah penyakit yang mempengaruhi sistem pernapasan dan ditularkan melalui tetesan dari mulut atau hidung ketika seseorang batuk atau bersin. Virus corona pertama kali ditemukan di Wuhan, China pada Desember 2019 dan pada 11 Maret 2020 Organisasi Kesehatan Dunia WHO menyatakan virus corona sebagai pandemi global. Pada 2 Maret 2020, virus corona resmi masuk ke Indonesia ketika Presiden Joko Widodo mengumumkan ada dua warga Indonesia positif terpapar COVID-19. Meningkatnya perkembangan COVID-19 di Indonesia membuat pemerintah mengambil berbagai kebijakan seperti Pembatasan Berskala Besar (PSBB) dan tatanan kehidupan normal baru (New Normal). Berbagai macam kebijakan yang telah diambil pemerintah belum mampu menekan angka COVID-19. Selain itu, pandemi COVID-19 setidaknya berdampak pada dua ranah, yakni setiap tingkatan aktor (level of anlysis) dan berbagai aspek kehidupan (aspects or issues). Dampak dari tingkatan aktor seperti individu, komunitas, masyarakat dan perusahaan. Demikian juga berbagai aspek kehidupan mulai dari aspek kesehatan, sosial, ekonomi dan politik (Valerisha and Putra 2020). 
Pandemi adalah wabah atau penyakit yang berjangkit secara bersama dengan penyebaran secara global diseluruh dunia. virus corona adalah virus yang umum ditemukan dilingkungan kita. virus ini ditemukan sejak pertengahan 1960 dan dikenal sebagai virus yang menyebabkan gejala batuk dan pilek. (Pradipta \& Ahmad, 2020)

Pemutusan hubungan kerja, berdampak kepada pengangguran, kesulitan mencari pekerjaan, masyarakat miskin meningkat. Prediksi peningkatan jumlah kemiskinan di Indonesia. Virus Corona kemudian muncul dan memberikan begitu banyak pengaruh dalam berbagai sektor. Salah satu sektor yang terdampak dan begitu terasa adalah sektor ekonomi. Hal ini menjadi merupakan isu terkini dan oleh karena itu penulis tertarik untuk membahas tantanga Perekonomian Indonesia menghadapi dari virus corona yang terjadi saat ini. Melihat dampak ekonomi akibat mewabahnya virus Covid-19 ini, maka pemerintah perlu mengambil langkah yang paling efektif untuk menjaga agar perekonomian Indonesia bisa tetap stabil. Sehingga ini bisa menjadi peluang sekaligus tantangan bagi pelaku ekonomi khususnya ekonomi syari'ah untuk mengambil peran dalam rangka membantu pemerintah menstabilkan ekonomi Indonesia. Mengingat bahwa bisnis syari'ah saat ini sedang berkembang dengan cukup baik. (Sumarni, 2020)

\section{METODE PENELITIAN}

\section{Metode Pengumpulan Data}

1. Observasi

Metode observasi dilakukan dengan memberikan kuesioner menggunakan google form yang dibagikan kepada responden untuk diisi sesuai dengan dampak yang dirasakan langsung oleh responden..

\section{Identifikasi masalah}

1. Bagaimana Dampak Covid-19 Terhadap Tenaga Kerja Di Indonesia ?.

2. Bagaimana Perlindungan Sosial Untuk Pekerja Rentan Covid-19 Terhadap Tenaga Kerja Di Indonesia?.

\section{HASIL DAN PEMBAHASAN}

Hasil dari penyebaran kuesioner kepada responden menggunakan Google form untuk mendapatkan data yang dibutuhkan. 
Apakah covid-19 sangat merugikan penghasilan anda?

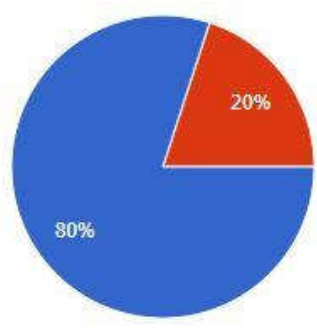

Apakah metode isolasi mandiri bagi yang terdampakan covid 19 sangat efektif bagi sekitarnya?

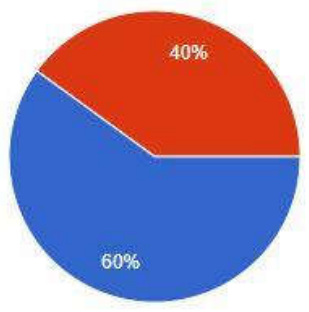

Gambar 1. Grafik Responden

Tabel Data Responden

\begin{tabular}{|c|c|c|c|}
\hline Responden & Sangat Merugikan & Tidak Merugikan & Jumlah \\
\hline sangat merugikan penghasilan & 80 & 20 & 100 \\
\hline metode isolasi mandiri & 60 & 40 & 100 \\
\hline Jumlah & 140 & 60 & 100 \\
\hline
\end{tabular}

Responden yang Terdampak Penghasilan Berkurang dan Sudah menerima bantuan : $140: 2=70$ orang

Responden yang Tidak Terdampak dan belum menerima bantuan :

$60: 2=30$ orang

\section{Dampak Covid-19 Terhadap Tenaga Kerja Di Indonesia}

Tenaga kerja adalah penduduk yang berada dalam usia kerja. Menurut UndangUndang Nomor 13 Tahun 2003 Bab I Pasal 1 ayat 2 disebutkan bahwa tenaga kerja adalah setiap orang yang mampu melakukan pekerjaan untuk menghasilkan barang atau jasa baik 
untuk memenuhi kebutuhan sendiri maupun untuk masyarakat. Secara garis besar penduduk suatu negara dibagi menjadi dua kelompok yaitu pekerja dan non pekerja. Penduduk digolongkan sebagai angkatan kerja jika penduduk tersebut telah memasuki usia kerja. Batas usia kerja di Indonesia adalah 15 tahun dan 64 tahun. Menurut pengertian ini, setiap orang yang mampu bekerja disebut tenaga kerja. Ada banyak pendapat mengenai usia pekerja ini, ada yang mengatakan di atas 17 tahun, ada yang mengatakan di atas 20 tahun, bahkan ada yang mengatakan di atas 7 tahun karena anak jalanan termasuk dalam tenaga kerja. (Benggolo, 2017)

Karantina dan gangguan terhadap dunia usaha, larangan bepergian, penutupan sekolah dan tindakan penutupan lainnya berdampak tiba-tiba dan drastis terhadap pekerja dan perusahaan. Seringkali yang pertama kehilangan pekerjaan adalah mereka yang pekerjaannya sudah rentan, seperti pekerja toko, pelayan, pekerja dapur, penangan bagasi, dan petugas kebersihan. Di dunia di mana hanya satu dari lima orang yang memenuhi syarat untuk tunjangan pengangguran, PHK adalah bencana bagi jutaan keluarga.

Pekerja informal, yang menyumbang sekitar 61 persen dari tenaga kerja global sangat rentan selama pandemic karena mereka harus menghadapi risiko K3 yang lebih tinggi dan kurangnya perlindungan yang memadai. Bekerja dengan tidak adanya perlindungan, seperti cuti sakit atau tunjangan pengangguran, membuat para pekerja ini mungkin perlu memilih antara kesehatan dan pendapatan, yang berisiko terhadap kesehatan mereka, kesehatan orang lain serta kesejahteraan ekonomi mereka. Selain pengangguran dan setengah pengangguran; krisis juga akan berdampak pada kondisi kerja, upah dan akses atas perlindungan sosial, dengan dampak negatif khususnya pada kelompok-kelompok tertentu yang lebih rentan terhadap dampak pasar kerja yang buruk. (Syahrial, 2020)

Pandemi juga dapat memiliki dampak ekonomi yang tidak proporsional pada segmen tertentu dari populasi, yang dapat memperburuk ketimpangan yang mempengaruhi sebagian besar kelompok pekerja, seperti :

a. Pekerja yang sudah memiliki masalah dengan kondisi kesehatan;

b. Kaum muda yang sudah menghadapi tingkat pengangguran dan setengah pengangguran yang lebih tinggi;

c. Pekerja yang lebih tua yang mungkin menghadapi risiko lebih tinggi terkena masalah kesehatan yang serius dan kemungkinan menderita kerentanan ekonomi;

d. Perempuan yang terlalu banyak mewakili pekerjaan-pekerjaan yang berada di garis depan dalam menangani pandemi dan yang akan menanggung beban yang tidak proporsional dalam tanggung jawab perawatan terkait dengan penutupan sekolah atau sistem keperawatan;

e. Pekerja yang tidak terlindungi, termasuk pekerja mandiri, pekerja kasual dan pekerja musiman (gig workers) yang tidak memunyai akses terhadap mekanisme cuti dibayar atau sakit; dan

f. Pekerja migran yang mungkin tidak dapat mengakses tempat kerja mereka di Negara tujuan ataupun kembali pulang kepada keluarga mereka. 


\section{Perlindungan Sosial Untuk Pekerja Rentan Covid-19 Terhadap Tenaga Kerja Di Indonesia}

Pada kenyataannya, dampak wabah Covid-19 menempatkan pekerja rentan sebagai salah satu kelompok masyarakat yang paling terdampak, walaupun ada perbedaan kondisi dan kebutuhan dari masing-masing jenis pekerjaan. Situasi tentang kapan berakhirnya wabah ini masih penuh tanda tanya besar, sehingga jika semakin lama kondisi ini berlangsung, maka akan semakin membawa pekerja rentan dalam kehidupan yang semakin tidak menentu.

Covid-19 merupakan penyakit yang baru saja ditemukan yang dimana merupakan menular yang berpotensi menimbulkan kedaruratan kesehatan masyarakat Oleh sebab itu, tindakan pencegahan terhadap jenis penyakit menular tersebut wajib dilakukan secepat mungkin. Dan covid 19 ini sudah membuat keresahan di belahan dunia dengan adanya covid19 membuat penurunan perekonomian di setiap negara yang warganya terjangkit covid-19 termasuk Indonesia, dalam beberapa bulan penulis melakukan observasi menggunakan kuesioner pada 50 responden dimana mendapatkan hasil diatas.

Untuk mengurangi dampak yang dihadapi oleh para pekerja rentan, pemerintah dapat mengambil kebijakan dalam dua bentuk. Pertama, selama masa pandemi berlangsung; kedua, pada saat pandemi ini telah berakhir.

Pada saat pandemi Covid-19 masih berlangsung, maka hal yang paling penting untuk dipenuhi adalah kebutuhan mendasar masyarakat, yaitu kebutuhan pokok. Kebijakan stimulus dari pemerintah perlu menyasar permasalahan ini. Saat ini pemerintah telah mengeluarkan kebijakan "kartu sembako", akan tetapi tidak semua pekerja rentan mendapatkannya. Hasil penelitian kami menunjukan bahwa delapan pekerja rentan yang kami wawancara, tidak ada satupun yang mendapatkan bantuan sosial dari pemerintah.

Melalui kebijakan pemenuhan kebutuhan pokok, maka pekerja rentan tidak perlu harus berhutang dan menguras tabungannya untuk memenuhi kebutuhan hidup sehari-hari. Langkah yang dapat dilakukan pemerintah adalah mendorong pendataan secara massal para pekerja rentan dan kelompok masyarakat lain yang perlu dipenuhi kebutuhan pokoknya, melalui perluasan "kartu sembako". Kebijakan ini dapat dimulai di daerah zona merah yang merupakan episentrum penularan Covid-19 dan tempat di mana aktivitas ekonomi mengalami penurunan yang drastis.

Kedua, pasca pandemi Covid-19 ada kebutuhan dari pekerja rentan, terutama pekerja mandiri yang memiliki bidang usaha, yaitu untuk mendapatkan kredit yang terjangkau. Dengan kredit yang murah dan terjangkau, maka para pedagang kecil dapat mengaksesnya, sehingga mereka akan tetap dapat menjalankan aktivitas ekonomi pasca-wabah ini berakhir. Selain itu, bagi para pekerja rentan dan "kelompok rentan baru", mereka membutuhkan agar tetap disokong kebutuhan pokoknya sampai akhirnya situasi ekonomi menjadi normal kembali.

Belajar dari pandemi Covid-19, kita dapat melihat bahwa masyarakat, terutama kelompok rentan, membutuhkan adanya jaminan kesehatan dan jaminan sosial. Pada situasi krisis seperti akibat pandemi Covid-19 ini, kategori kelompok rentan tidak hanya pekerja mandiri, pekerja keluarga tidak dibayar, dan pekerja lepas, namun ada kelompok rentan baru, yaitu mereka yang terlempar dari pekerjaan layak. Kelompok rentan baru ini adalah para pekerja formal yang di PHK atau dirumahkan akibat terjadinya krisis. Hal tersebut, menjadikan kondisi hidup mereka sama tidak menentunya dengan para pekerja rentan yang lain, walaupun, mereka cenderung memiliki tabungan lebih banyak atau keterampilan mumpuni disbanding pekerja rentan yang lain. 
Ketidak menentuan dan kesulitan hidup menjadikan kelompok rentan ini memerlukan jaring pengaman sosial, seperti jaminan kesehatan dan jaminan sosial. Melalui penyediaan jaminan kesehatan dan jaminan sosial, maka kehidupan masyarakat yang paling rentan menjadi terlindungi, baik pada saat tidak ada krisis maupun pada saat krisis. Dengan adanya perlindungan sosial ini, pekerja rentan dapat tetap hidup dalam kondisi sehat dan tetap mampu bekerja untuk memenuhi kehidupan mereka dan keluarganya pada hari depan. Tanpa jaminan kesehatan dan jaminan sosial, maka krisis akibat pandemi Covid-19 ini akan merenggut harapan dan kehidupan kelompok rentan.

Di negara Kondisi berkembang pada umumnya memiliki tingkat pengangguran yang jauh lebih tinggi dari angka resmi yang dikeluarkan oleh pemerintah. Hal ini terjadi karena ukuran sektor informal masih cukup besar sebagai salah satu lapangan nafkah bagi tenaga kerja tidak terdidik. Sektor informal tersebut dianggap sebagai katup pengaman bagi pengangguran. Masalah ketenagakerjaan di Indonesia sekarang ini sudah mencapai kondisi yang cukup memprihatinkan ditandai dengan jumlah penganggur dan setengah penganggur yang besar, pendapatan yang relatif rendah dan kurang merata. Sebaliknya pengangguran dan setengah pengangguran yang tinggi merupakan pemborosan pemborosan sumber daya dan potensi yang ada, menjadi beban keluarga dan masyarakat, sumber utama kemiskinan, dapat mendorong peningkatan keresahan sosial dan kriminal, dan dapat menghambat pembangunan dalam jangka panjang.

Berikut ini beberapa masalah ketenagakerjaan di Indonesia :

a. Rendahnya kualitas tenaga kerja, Kualitas tenaga kerja dalam suatu negara dapat ditentukan dengan melihat tingkat pendidikan negara tersebut. Sebagian besar tenaga kerja di Indonesia, tingkat pendidikannya masih rendah. Hal ini menyebabkan penguasaan ilmu pengetahuan dan teknologi menjadi rendah. Minimnya penguasaan ilmu pengetahuan dan teknologi menyebabkan rendahnya produktivitas tenaga kerja, sehingga hal ini akan berpengaruh terhadap rendahnya kualitas hasil produksi barang dan jasa.

b. Jumlah angkatan kerja yang tidak sebanding dengan kesempatan kerja, Meningkatnya jumlah angkatan kerja yang tidak diimbangi oleh perluasan lapangan kerja akan membawa beban tersendiri bagi perekonomian. Angkatan kerja yang tidak tertampung dalam lapangan kerja akan menyebabkan pengangguran. Padahal harapan pemerintah, semakin banyaknya jumlah angkatan kerja bisa menjadi pendorong pembangunan ekonomi.

c. Persebaran tenaga kerja yang tidak merata, Sebagian besar tenaga kerja di Indonesia berada di Pulau Jawa. Sementara di daerah lain masih kekurangan tenaga kerja, terutama untuk sektor pertanian, perkebunan, dan kehutanan. Dengan demikian di Pulau Jawa banyak terjadi pengangguran, sementara di daerah lain masih banyak sumber daya alam yang belum dikelola secara maksimal.

d. Pengangguran, Terjadinya krisis ekonomi di Indonesia banyak mengakibatkan industri di Indonesia mengalami gulung tikar. Akibatnya, banyak pula tenaga kerja yang berhenti bekerja. Selain itu, banyaknya perusahaan yang gulung tikar mengakibatkan semakin sempitnya lapangan kerja yang ada. Di sisi lain jumlah angkatan kerja terus meningkat. Dengan demikian pengangguran akan semakin banyak.

e. Problem Gaji/UMR, Salah satu problem yang langsung menyentuh kaum buruh adalah rendahnya atau tidak sesuainya pendapatan (gaji) yang diperoleh dengan tuntutan untuk memenuhi kebutuhan hidupnya beserta tanggungannya. Faktor ini, yakni kebutuhan 
hidup semakin meningkat, sementara gaji yang diterima relatif tetap, menjadi salah satu pendorong gerak protes kaum buruh. Adapun dalam sistem ekonomi Kapitalis, rendahnya gaji buruh justru menjadi penarik bagi para investor asing. Termasuk pemerintah, untuk kepentingan peningkatan pendapatan pemerintah (bukan rakyat), justru memelihara kondisi seperti ini. Kondisi ini menyebabkan pihak pemerintah lebih sering memihak ,sang investor ${ }^{\text {ee }}$, disbanding dengan buruh (yang merupakan rakyatnya sendiri) ketika terjadi krisis perburuhan. Rendahnya gaji juga berhubungan dengan rendahnya kualitas SDM. Persoalannya bagaimana, SDM bisa meningkat kalau biaya pendidikan mahal. Solusi terhadap problem UMR dan UMD ini tentu saja harus terus diupayakan dan diharapkan mampu membangun kondisi seideal mungkin.

Maka dari pada itu, pengusaha dan organisasi mereka harus mematuhi saran yang diberikan oleh otoritas nasional dan lokal, termasuk terkait pengaturan kerja dan mengomunikasikan informasi penting kepada pekerja. Mereka harus menilai potensi risiko gangguan terhadap usaha, meninjau atau menyusun rencana kesinambungan usaha yang konsisten dengan pedoman yang diberikan oleh otoritas nasional dan lokal demi meningkatkan ketahanan usaha dan mendukung pekerja dan keluarga mereka. Pengusaha harus mengidentifikasi dan mengurangi risiko terhadap pekerja dan orang lain terkait dengan tempat kerja yang diakibatkan oleh wabah dan mempromosikan kebersihan di tempat kerja. Mereka juga harus menilai tanggung jawab perusahaan untuk kompensasi pekerja, khususnya di sektor-sektor berisiko tinggi, serta mencari saran dan dukungan dari pengusaha dan organisasi keanggotaan bisnis yang dapat menyalurkan keprihatinan kepada pemerintah dan membentuk langkah-langkah kebijakan yang kondusif untuk ketahanan dan keberlanjutan usaha.

\section{KESIMPULAN}

Berdasarkan uraian diatas, maka penarikan kesimpulannya adalah sebagai berikut :

1. Pandemi juga dapat memberikan dampak ekonomi yang tidak proporsional pada segmen populasi tertentu, yang dapat memperburuk ketidaksetaraan yang mempengaruhi sebagian besar kelompok pekerja dan usaha mikro, seperti: Pekerja yang sudah memiliki masalah dengan kondisi kesehatan, Pemuda yang sudah menghadapi tingkat pengangguran yang tinggi dan setengah pengangguran yang lebih tinggi, Pekerja yang lebih tua yang mungkin berisiko lebih tinggi mengalami masalah kesehatan yang serius dan mungkin menderita kerentanan ekonomi, Wanita yang terlalu terwakili dalam pekerjaan yang berada di garis depan dalam menangani pandemi dan yang akan menanggung beban yang tidak semestinya secara tidak proporsional dalam tanggung jawab perawatan yang terkait dengan penutupan sekolah atau sistem keperawatan, Pekerja tidak terlindungi, termasuk wiraswasta, pekerja lepas dan pekerja pertunjukan yang tidak memiliki akses ke mekanisme cuti berbayar atau sakit dan Pekerja migran yang mungkin tidak memiliki akses ke mekanisme cuti berbayar atau sakit. dapat mengakses tempat kerja mereka di negara tujuan atau pulang ke keluarga mereka.

2. Pandemi Covid-19 berdampak besar terhadap penurunan perekonomian nasional, termasuk sektor UMKM. Namun seiring dengan penurunan angka penularan Covid-19 dan program vaksinasi yang berjalan, sektor UMKM optimistis bisa pulih pada 2021. Sejak 2020, pemerintah telah mengeluarkan berbagai kebijakan untuk mendukung pemulihan sektor UMKM, termasuk penyaluran PEN untuk sektor UMKM, program 
Gernas BBI, program vaksinasi, restrukturisasi kredit, dan rencana pembentukan holding BUMN ultra mikro. DPR RI melalui komisi-komisi terkait perlu memberikan dukungan dan perhatian kepada pemerintah dalam melaksanakan kebijakan yang diambil untuk memulihkan sektor UMKM agar momentum pertumbuhan ekonomi tahun 2021 dapat terwujud.

\section{DAFTAR PUSTAKA}

1. Yang,L., \& Ren, Y. (2020). Moral Obligation, Public Leadership, and Collective Action for Epidemic Prevention and Control: Evidence from the Corona Virus Disease 2019 (COVID-19) Emergency. International Journal of Environmental Research and Public Health, 17(8), 1-16. https://doi.org/10.3390/ijerph17082731

2. Detik.com, 2020. Jumlah Pekerja Dirumahkan dan Kena PHK Naik Jadi 1,5 Juta. https://finance.detik.com/beritaekonomi-bisnis/d-4973759/jumlahpekerja-dirumahkandan-kena-phknaik-jadi-15-juta. [Online] Tersedia: [11 April 2020].

3. Gugus Tugas Percepatan Penanganan Covid-19. (2020). Situasi virus COVID-19 di Indonesia.

4. Pradipta, J., \& Ahmad, M,N. 2020. ANTIPANIK! Buku Panduan Virus Corona. Jakarta : PT Elex Media Komputindo

5. Valerisha, A., \& Putra, M. A. (2020). Pandemi Global COVID-19 dan Problematika Negara-Bangsa: Transparansi Data Sebagai Vaksin Socio-digital? Jurnal Ilmiah Hubungan Internasional, 131-137

6. Sumarni, Yenti. 2020. "Pandemi Covid-19: Tantangan Ekonomi Dan Bisnis." Al-Intaj : Jurnal Ekonomi Dan Perbankan Syariah 6 (2): 46-58

7. Syahrial, S. 2020. DAMPAK COVID-19 TERHADAP TENAGA KERJA DI INDONESIA. JURNAL NERS, 4(2), 21-29 